\title{
UJI AKTIVITAS ANTIBAKTERI EKSTRAK DAUN BINAHONG (Anredera cordifolia (Ten.) Steenis) TERHADAP PERTUMBUHAN BAKTERI Staphylococcus aureus DAN Pseudomonas aeruginosa
}

\author{
TEST OF ANTIBACTERIAL ACTIVITY OF LEAF EXTRACT BINAHONG \\ (Anredera cordifolia (Ten.) Steenis) ON GROWTH OF BACTERIA Staphylococcus \\ aureus AND Pseudomonas aeruginosa
}

\author{
Ani Sulistyarsi ${ }^{1}$, Nanda Wahyu Pribadi ${ }^{2}$ \\ ${ }^{1}$ Program Studi Farmasi FIKS, Universitas PGRI Madiun, Indonesia \\ ${ }^{2}$ Program studi Pendidikan Biologi FKIP, Universitas PGRI Madiun, Indonesia \\ anisulistyarsi@unipma.ac.id
}

\begin{abstract}
Abstrak
Tumbuhan obat telah digunakan sejak dahulu secara turun temurun untuk mencegah, menyembuhkan serta memelihara kesehatan. Penelitian ini bertujuan untuk mengetahui pengaruh ekstrak daun binahong (Anredera cordifolia (Ten.) Steenis) terhadap pertumbuhan bakteri Staphylococcus aureus dan Pseudomonas aeruginosa. Penelitian menggunakan rancangan acak lengkap 7 perlakuan, 3 kali ulangan. Ekstrak binahong dengan uji maserasi menggunakan etil asetat. Konsentrasi ekstrak binahong menggunakan kontrol $(0 \%)$, 25\%, 30\%, 35\%, 40\%, 45\%, 50\% untuk bakteri Staphylococcus aureus dan Pseudomonas aeruginosa. Data dianalisis dengan uji oneway ANOVA, korelasi dan regresi linear. Hasil penelitian KHM ekstrak binahong terhadap bakteri Staphylococcus aureus pada konsentrasi 25\%, pada bakteri Pseudomonas aeruginosa: konsentrasi 50\%. Pada uji KBM ekstrak binahong terhadap bakteri Staphylococcus aureus dengan konsentrasi 50\%, pada bakteri Pseudomonas aeruginosa dengan konsentrasi $100 \%$. Hasil uji oneway ANOVA: ada perbedaan yang bermakna antar perlakuan. Nilai sig $(0,000)<\mathrm{p}(0,05)$. Semakin tinggi konsentrasi ekstrak binahong, semakin mampu menghambat dan membunuh bakteri Staphylococcus aureus $(\mathrm{r}=-0,805)$, Pseudomonas aureginosa $(\mathrm{r}=-0,616)$. Hasil uji fitokimia ditemukan senyawa polifenol, alkaloid dan flavanoid.
\end{abstract}

Kata kunci: Binahong; Staphylococcus aureus; Pseudomonas aeruginosa

\begin{abstract}
Medicinal plants have been used from generation to generation to prevent, heal and maintain health. The aim of this research is to know the effect of binahong leaf extract (Anredera cordifolia (Ten.) Steenis) on the growth of Staphylococcus aureus and Pseudomonas aeruginosa bacteria. The design of the study was a complete randomized design of 7 treatments, 3 replications. Binary extract by maceration test using ethyl acetate. The concentration of binahong extract used control (0\%), 25\%, 30\%, 35\%, 40\%, 45\%, 50\% for Staphylococcus aureus and Pseudomonas aeruginosa bacteria. Data were analyzed by ANOVA oneway test, correlation and linear regression. The result showed that binahong against Staphylococcus aureus bacteria at 25\% concentration, on bacterium Pseudomonas aeruginosa: concentration 50\%. Extract binahong test of Staphylococcus aureus bacteria with concentration 50\%, on bacterium Pseudomonas aeruginosa with 100\% concentration. ANOVA oneway test results: there is a significant difference between treatments. The value of sig $(0,000)<p(0.05)$. The higher the concentration of binahong extract, the more able to inhibit and kill the bacteria Staphylococcus aureus $(r=-0,805)$, Pseudomonas aureginosa $(r=-0.616)$. The results of phytochemical tests found polyphenolic compounds, alkaloids and flavonoids
\end{abstract}

Keywords:Binahong leaf; Staphylococcus aureus; Pseudomonas aeruginosa 


\section{PENDAHULUAN}

Indonesia merupakan negara agraris yang kaya akan keanekaragaman hayati termasuk tumbuhan obat yang telah digunakan sejak dahulu secara turun temurun untuk mencegah, menyembuhkan serta memelihara kesehatan. Dewasa ini penggunaan obat tradisional sebagai alternatif pengobatan mengalami peningkatan. Hal ini disebabkan kecenderungan masyarakat menerapkan gaya hidup back to nature atau kembali ke alam serta ditunjang oleh efek samping obat tradisional yang relatif kecil dan harganya dapat dijangkau oleh masyarakat luas. Binahong (Anredera cordifolia (Ten) Steenis) atau dalam bahasa Tiongkok dikenal dengan nama Dheng San Chi adalah tanaman obat, asli dari Amerika Selatan (Astuti, 2011: 2). Secara empiris, masyarakat di pulau Jawa memanfaatkan untuk membantu proses penyembuhan beragam penyakit, termasuk untuk mengobati luka sehabis operasi caesar atau memulihkan tenaga ibu setelah bersalin. Akar dan daun tanaman binahong bermanfaat sebagai obat penyembuh luka bekas operasi, penyakit tiphus, radang usus, asam urat, disentri dan wasir (Setiaji, 2009: 2).

Menurut Manoi (2009: 5) zat bioaktif dalam tanaman binahong dapat membantu proses penyembuhan penyakit-penyakit degeneratif seperti kerusakan ginjal, diabetes, pembengkakan jantung, stroke, wasir dan asam urat. Dalam penelitian lain yang dilakukan Tshikalange et al (2005: 2) tanaman binahong dapat mengobati penyakit infeksi yang disebabkan oleh bakteri, bahkan ekstrak daun dan umbi binahong dapat mengobati infeksi penyakit kelamin seperti penyakit syphilis. Tanaman binahong mengandung fenol, flavonoid, saponin, triterpenoid, steroid dan alkaloid, selain itu memiliki aktifitas sebagai antioksidan (Astuti et al 2011: 225).

Menurut hasil penelitian Marinova et al (2005: 255) senyawa fenolik dan flavonoid termasuk dalam metabolit sekunder dari tanaman yang mempunyai aktifitas biologi dan terdiri dari 8000 macam senyawa. Senyawa ini dapat berperan langsung sebagai antibiotika dengan mekanisme kerja menghancurkan sel dinding bakteri. Fenolik dan flavonoid juga memiliki aktifitas sebagai antioksidan. Metabolit sekunder lainnya adalah saponin yang memiliki aktifitas pada permukaan. Tanaman binahong memiliki kandungan senyawa saponin yang lebih besar dari pada senyawa lainnya, terutama pada umbi. Saponin termasuk senyawa glikon (gula) dan senyawa aglikon, adapun senyawa aglikon adalah termasuk golongan steroid dan terpenoid. Senyawa terpenoid adalah senyawa hidrokarbon isometrik yang membantu proses sintesa organik dan pemulihan sel-sel tubuh. Saponin mempunyai fungsi menurunkan kolesterol karena mempunyai aktifitas sebagai antioksidan (Manoi, 2009: 4).

Bakteri Staphylococcus aureus dan Pseudomonas aeruginosa merupakan patogen terpenting dan berbahaya di antara marga Staphylococcus dan Pseudomonas. Keduanya sering resisten terhadap berbagai jenis obat, sehingga mempersulit pemilihan antimikroba yang sesuai untuk terapi. Resistensi terhadap beberapa antimikroba umumnya terjadi di rumah sakit, tempat yang paling banyak menggunakan antimikroba. Hasil uji kepekaan terhadap antimikroba yang digunakan di RSU Dr. Soetomo Surabaya selama bulan Agustus 2005 sampai dengan Februari 2006 menunjukan bahwa sebesar $74,1 \%$ isolat Staphylococcus aureus mengalami resistensi multiobat dan sebanyak $95,9 \%$ isolat Pseudomonas aeruginosa mengalami resistensi multiobat. Resistensi multiobat didefinisikan sebagai resistensi terhadap dua atau lebih jenis antimikroba yang berbeda.

Berdasarkan uraian tentang tanaman binahong (Anredera cordifolia (Ten.) Steenis) dan potensi yang dimiliki sebagai tanaman obat antibakteri Staphylococcus aureus dan Pseudomonas aeruginosa di atas maka penelitian ini bertujuan untuk menguji aktivitas antibakteri dengan berbagai konsentrasi ekstrak daun binahong terhadap bakteri Staphylococcus aureus multiresisten antibiotik yang mewakili gram positif dan 
Pseudomonas aeruginosa multiresisten antibiotik yang mewakili gram negatif. Hasil penelitian tentang uji aktivitas antibakteri ekstrak daun binahong (Anredera cordifolia (Ten.) Steenis) terhadap pertumbuhan bakteri Staphylococcus aureus dan Pseudomonas aeruginosa dapat menyediakan informasi yang lengkap dan bermanfaat dalam pembelajaran Biologi, khusunya pada mata kuliah mikrobiologi. Rumusan masalah pada penelitian ini adalah adakah pengaruh ekstrak daun binahong (Anredera cordifolia (Ten.) Steenis) terhadap pertumbuhan bakteri Staphylococcus aureus dan Pseudomonas aeruginosa. Tujuan penelitian ini adalah untuk mengetahui pengaruh ekstrak daun binahong (Anredera cordifolia (Ten.) Steenis) terhadap pertumbuhan bakteri Staphylococcus aureus dan Pseudomonas aeruginosa dan menyusun sebagian hasil penelitian tentang uji aktivitas antibakteri ekstrak daun binahong (Anredera cordifolia (Ten.) Steenis) terhadap pertumbuhan bakteri Staphylococcus aureus dan Pseudomonas aeruginosa untuk petunjuk praktikum.

\section{METODE}

Penelitian ini merupakan penelitian eksperimental. Rancangan penelitian untuk menguji konsentrasi ekstrak daun Binahong Anredera cordifolia (Ten.) Steenis, dengan variasi konsentrasi terhadap pertumbuhan bakteri Staphylococcus aureus dan Pseudomonas aeruginosa. Untuk mengetahui daya antibakteri semua kondisi perlakuan dibuat sama, kecuali pemberian konsentrasi ekstrak daun Binahong Anredera cordifolia (Ten.) Steenis yang dibuat berbeda. Rancangan penelitian yang digunakan dalam penelitian ini adalah rancangan acak lengkap (RAL), dengan 7 perlakuan konsentrasi ekstrak daun binahong konsentrasi $(0 \%, 25 \%$, $30 \%, 35 \%, 40 \%, 45 \%$ dan $50 \%$ ) untuk bakteri Staphylococcus aureus dan untuk bakteri Pseudomonas aeruginosa, dan 3 ulangan pada masing-masing bakteri.

\section{Alat dan bahan}

Alat-alat yang digunakan dalam penelitian ini dapat dikelompokkan menjadi dua, yaitu alat-alat untuk ekstraksi maserasi dan uji fitokimia serta alat-alat untuk uji antibakteri. Alat-alat untuk ekstraksi maserasi dan uji fitokimia meliputi timbangan analitik, oven, blender, shaker, rotary evaporator vacuum, penyaring Buchner, gelas ukur $10 \mathrm{ml}$, Erlenmeyer $500 \mathrm{ml}$ dan $1 \mathrm{~L}$, beacker glass 100 $\mathrm{ml}$, tabung reaksi, mikro pipet, pengaduk kaca, kertas saring/whatman, dan alumunium foil. Sedangkan alat-alat untuk uji antibakteri meliputi autoklaf, incubator, lampu Bunsen, labu Erlenmeyer $250 \mathrm{ml}$, cawan petri, tabung reaksi, paper disk, gelas ukur, mikro pipet, pinset, ent-kas, jangka sorong, colony counter, jarum ose, strirer, kertas label, kertas cakram, kapas dan kertas coklat, serta mikroskop. Bahan-bahan yang digunakan dalam penelitian ini terdiri dari ekstrak daun Binahong Anredera cordifolia (Ten.) Steenis, biakkan murni bakteri Staphylococcus aureus dan Pseudomonas aeruginosa, media Nutrien Agar (NA), media cair Nutrient Broth (NB), aquades, tween 80, etil asetat, dan alkohol $70 \%$.

\section{Prosedur kerja}

\section{Uji Aktifitas Antibakteri Ekstrak Daun Binahong}

Uji kepekaan kuman terhadap antimikroba dilakukan dengan menggunakan metode dilusi tabung (tube dilution test) untuk mengetahui konsentrasi hambat minimum (KHM) dan konsentrasi bunuh minimum (KBM) dengan melakukan penanaman bakteri pada media Nutrient Broht (NB) dan media Nutrient Agar (NA) pada cawan petri dengan pemberian konsentrasi ekstrak daun binahong sesuai dengan perlakuan perhitungan konsentrasi ekstrak daun binahong.

\section{Penghitungan Data}

Setelah biakan diinkubasi selama 18-24 jam pada suhu $37^{\circ} \mathrm{C}$ lalu dilakukan pengamatan biakan bakteri dan dihitung dengan menggunakan Colony Counter. Biakan 
yang dihitung diambil koloni yang tumbuh sesuai dengan standar plat count yaitu 30-300 koloni per cawan.

\section{Analisa data}

\section{Analisis Koloni Bakteri}

Data yang diperoleh yaitu data konsentrasi ekstrak daun binahong dan jumlah koloni bakteri. Analisis yang digunakan adalah uji statistik one way ANOVA, uji korelasi dan uji regresi linear sederhana. Uji one way ANOVA digunakan untuk mengetahui adanya pengaruh pemberian berbagai konsentrasi ekstrak daun binahong terhadap pertumbuhan jumlah koloni bakteri Staphylococcus aureus dan Pseudomonas aeruginosa. Jika ada pengaruh, maka dilanjutkan dengan menggunakan uji lanjut LSD (Least Significant Differences). Sedangkan untuk mengetahui hubungan antara peningkatan konsentrasi ekstrak daun binahong terhadap jumlah koloni bakteri Staphylococcus aureus dan Pseudomonas aeruginosa maka digunakan uji Korelasi. Sedangkan untuk mencari kekuatan hubungan yang ada antara peningkatan konsentrasi ekstrak daun Binahong dengan penurunan jumlah koloni bakteri Staphylococcus aureus dan Pseudomonas aeruginosa digunakan uji regresi linear. Analisis data dilakukan dengan menggunakan program SPSS for windows versi 16.

\section{HASIL DAN PEMBAHASAN}

\section{Identifikasi Golongan Senyawa Aktif}

Uji fitokimia adalah uji kualitatif kandungan senyawa aktif dalam suatu sampel. Analisis kandungan kimia daun binahong dilakukan di UPT Lab. Pusat MIPA UNS (UPT LPM UNS) Sub. Lab Kimia, dengan melihat ada tidaknya reaksi pengendapan dan perubahan warna yang terjadi pada uji tabung. Uji fitokimia dengan metode tabung serta pendeteksian dengan menggunakan Spectrofotometer, dari hasil uji didapatkan data bahwa ekstrak etil asetat daun binahong mengandung senyawa Flavanoid, Alkaloid dan Polifenol.

Tabel 1. Hasil Uji Fitokimia Secara Kualitatif

\begin{tabular}{|l|c|c|c|c|c|}
\hline \multirow{2}{*}{ Golongan Senyawa } & \multicolumn{5}{|c|}{ Pereaksi } \\
\cline { 2 - 6 } & Mayer & Dragendrof & Mg & HCL Pekat & FeCL $31 \%$ \\
\hline Alkaloid & + & + & & & \\
\hline Flavonoid & & & + & + & \\
\hline Polifenol & & & & & + \\
\hline
\end{tabular}

Sumber: Hasil Uji Fitokimia, UPT Lab. Pusat MIPA UNS, Sub. Lab Kimia

Keterangan: (+) menunjukkan positif

\section{Uji Konsentrasi Hambat Minimum (KHM) Ekstrak Daun Binahong terhadap Bakteri Staphylococcus aureus dan Pseudomonas aeruginosa}

Hasil uji pendahuluan penentuan konsentrasi hambat minimum (KHM) ekstrak daun binahong metode dilusi tabung secara serial dengan perlakuan konsentrasi yang telah ditambahkan suspensi bakteri Staphylococcus aureus dan Pseudomonas aeruginosa dan ekstrak daun binahong setelah diinkubasikan pada suhu $37^{\circ} \mathrm{C}$ selama $18-24$ jam dan dibandingkan dengan kontrol bakteri dan kontrol media dengan melihat kekeruhan sampel uji, setelah dilakukan pengamatan secara kualitatif didapatkan hasil sebagai berikut: 


\section{Journal of Pharmaceutical Science and Medical Research ISSN 2614-4840 (print) 2614-6118 (online) \\ Vol. 1 No. 1 Tahun 2018}

Tabel 2. Tingkat Kekeruhan yang Dihasilkan Pada Media Nutrient Agar oleh Koloni Bakteri Staphylococcus aureus dalam Konsentrasi Ekstrak Daun Binahong (Anredera cordifolia (Ten) Steenis)

\begin{tabular}{|c|l|}
\hline Konsentrasi & \multicolumn{1}{|c|}{$\begin{array}{c}\text { Tingkat Kekeruhan Media Pertumbuhan } \\
\text { Bakteri Staphylococcus aureus }\end{array}$} \\
\hline $100 \%$ & Bening/ Tidak ada bakteri yang tumbuh \\
\hline $50 \%$ & Bening/ Tidak ada bakteri yang tumbuh \\
\hline $25 \%$ & Bening/ Tidak ada bakteri yang tumbuh \\
\hline $12,5 \%$ & Keruh/ Ada bakteri yang tumbuh \\
\hline $6,25 \%$ & Keruh/ Ada bakteri yang tumbuh \\
\hline $3,125 \%$ & Keruh/ Ada bakteri yang tumbuh \\
\hline
\end{tabular}

Tabel 3. Tingkat Kekeruhan yang Dihasilkan Pada Media Nutrient Agar oleh Koloni Bakteri Pseudomonas aeruginosa dalam Konsentrasi Ekstrak Daun Binahong (Anredera cordifolia (Ten) Steenis)

\begin{tabular}{|c|l|}
\hline Konsentrasi & \multicolumn{1}{|c|}{$\begin{array}{c}\text { Tingkat Kekeruhan Media Pertumbuhan } \\
\text { Bakteri Pseudomonas aeruginosa }\end{array}$} \\
\hline $100 \%$ & Bening/ Tidak ada bakteri yang tumbuh \\
\hline $50 \%$ & Bening/ Tidak ada bakteri yang tumbuh \\
\hline $25 \%$ & Agak keruh/ Ada bakteri yang tumbuh \\
\hline $12,5 \%$ & Keruh/ Ada bakteri yang tumbuh \\
\hline $6,25 \%$ & Keruh/ Ada bakteri yang tumbuh \\
\hline $3,125 \%$ & Keruh/ Ada bakteri yang tumbuh \\
\hline
\end{tabular}

Hasil pengamatan ini sulit untuk dievaluasi, karena hasil dari pengenceran secara dilusi tabung pada konsentrasi $100 \%$ sampai dengan $3,125 \%$, menunjukkan tingkat kekeruhan yang sama pada semua tabung, hal ini dikarenakan warna dasar dari ekstrak daun binahong adalah hijau kehitaman. Maka untuk mengetahui pengaruh pemberian konsentrasi ekstrak daun binahong terhadap bakteri Staphylocoocus aureus dan Pseudomonas aeruginosa dilakukan Streaking (penggoresan) pada media Nutrient Agar dengan menanamkan I Ose dari hasil uji dilusi tabung. Setelah dilakukan Streaking didapatkan konsentrasi hambat minimum (KHM) ekstrak daun binahong Anredera cordifolia (Ten) Steenis terhadap bakteri Staphylococcus aureus yaitu pada konsentrasi 25\% (250 $\mathrm{mg} / \mathrm{ml}$ ), sedangkan konsentrasi hambat minimum (KHM) pada bakteri Pseudomonas aureginosa pada konsentrasi 50\% (500 mg/ml) yang ditandai dengan tidak adanya kekeruhan pada cawan. Pada medium yang keruh berarti bakteri masih dapat tumbuh, berarti antibiotic tidak efektif, sedangkan bila medium jernih berarti antibiotik efektif dalam menghambat pertumbuhan bakteri.

Dari hasil uji pendahuluan kemudian dilakukan uji lanjut untuk mengetahui konsentrasi bunuh minimum (KBM). Dengan menggunakan konsentrasi ekstrak daun binahong dari hasil uji KHM yaitu pada konsentrasi $25 \%(250 \mathrm{mg} / \mathrm{ml})$ sampai dengan $50 \% \quad(500 \quad \mathrm{mg} / \mathrm{ml})$ untuk bakteri Staphylococcus aureus dan pada bakteri Pseudomonas aeruginosa. Konsentrasi bunuh minimum (KBM) ditentukan jika pada plate didapatkan penurunan jumlah koloni bakteri sampai $99,9 \%$ dari bakteri asal sub-biakan. Pada uji konsentrasi bunuh minimum (KBM) perlakuan konsentrasi ekstrak diberi suspensi bakteri sebanyak $1 \mathrm{ml}\left(10^{6}\right)$ dan diinkubasi pada suhu $37^{\circ} \mathrm{C}$ selama $18-24$ jam, kemudian diencerkan. Pengenceran dilakukan dengan 


\section{Journal of Pharmaceutical Science and Medical Research}

ISSN 2614-4840 (print) 2614-6118 (online)

Vol. 1 No. 1 Tahun 2018

melihat terlebih dahulu kepadatan sel bakteri pada kamar hitung (Haemocytometer) dan diamati dengan menggunakan mikroskop. Sampel diencerkan sebanyak $10^{1}, 10^{2}, 10^{3}$ sampai $10^{5}$ dengan cara mengambil $1 \mathrm{ml}$ sampel kemudian dicampur ke dalam larutan $\mathrm{NaCL}$ fisiologis $09 \%$ sebanyak $9 \mathrm{ml}$, kemudian divortek. Hasil pengenceran di Streaking (gores) pada media NAP dan diinkubasi pada suhu $37^{\circ} \mathrm{C}$ selama $18-24$ jam, kemudian dihitung jumlah koloninya dengan menggunakan colony counter.

Uji Konsentrasi Bunuh Minimum (KBM) Ekstrak Daun Binahong terhadap Bakteri Staphylococcus aureus dan Pseudomonas aeruginosa

Pengaruh konsentrasi ekstrak daun Binahong terhadap jumlah koloni bakteri Staphylococcus auereus per $\mathrm{ml}\left(10^{6}\right)$ ditunjukkan pada tabel 4 sebagai berikut.

Tabel 4. Pengaruh Konsentrasi Ekstrak Daun Binahong (Anredera cordifolia (Ten) Steenis terhadap Jumlah Koloni Bakteri Staphylococcus aureus per $\mathrm{ml}\left(10^{6}\right)$

\begin{tabular}{|l|r|r|r|r|}
\hline \multirow{2}{*}{ Konsentrasi } & \multicolumn{3}{|c|}{ Ulangan } & \multirow{2}{*}{ Rerata } \\
\cline { 2 - 4 } & \multicolumn{1}{|c|}{ I } & \multicolumn{1}{c|}{ II } & \multicolumn{1}{c|}{ III } & \\
\hline Kontrol positif (0\%) & 301000 & 311000 & 305000 & 305666.67 \\
\hline $25 \%$ & 300000 & 303000 & 294000 & 299000 \\
\hline $30 \%$ & 297000 & 285000 & 290000 & 290666.67 \\
\hline $35 \%$ & 18600 & 27900 & 15500 & 20666.67 \\
\hline $40 \%$ & 9440 & 8290 & 1380 & 6370 \\
\hline $45 \%$ & 1370 & 1510 & 1430 & 1436.67 \\
\hline $50 \%$ & 0 & 0 & 0 & 0 \\
\hline
\end{tabular}

Dari tabel 4 dapat dilihat bahwa rata-rata jumlah koloni bakteri Staphylococcus aureus per $\mathrm{ml}\left(10^{6}\right)$ yang dihasilkan pada media NAP berbeda pada tiap perlakuan konsentrasi. Pada konsentrasi 0\% rata-rata jumlah koloni bakteri Staphylococcus aureus per $\mathrm{ml}\left(10^{6}\right)$ adalah sebesar 305666.67. Jumlah rata-rata koloni bakteri Staphylococcus aureus per $\mathrm{ml}\left(10^{6}\right)$ terus mengalami penurunan. Mulai dari konsentrasi 25\%, 30\%, 35\%, 40\%, 45\% sampai pada konsentrasi 50\%. Pada konsentrasi $50 \%$ tidak didapatkan pertumbuhan bakteri Staphylococcus aureus per ml $\left(10^{6}\right)$, ditunjukkan pada media NAP tidak ada bakteri yang tumbuh. Pada penelitian ini KBM ekstrak daun Binahong terhadap bakteri Staphylococcus aureus ditentukan pada konsentrasi $50 \%$. Konsentrasi bunuh minimum (KBM) ditentukan jika pada plate tidak menunjukkan pertumbuhan koloni bakteri atau ada penurunan $99,9 \%$ dari inokulum asal pada sub-biakan.

Hasil pengamatan pengaruh konsentrasi ekstrak daun binahong terhadap pertumbuhan koloni bakteri Pseudomonas aeruginosa pada media Nutrien Agar Plate (NAP) pada tiap perlakuan konsentrasi ekstrak daun binahong. Sedangkan pengaruh konsentrasi ekstrak daun Binahong terhadap jumlah koloni bakteri Pseudomonas aeruginosa per $\mathrm{ml}\left(10^{6}\right)$ sebagai berikut: 


\section{Journal of Pharmaceutical Science and Medical Research \\ ISSN 2614-4840 (print) 2614-6118 (online) \\ Vol. 1 No. 1 Tahun 2018}

Tabel 5. Pengaruh Konsentrasi Ekstrak Daun Binahong (Anredera cordifolia (Ten) Steenis terhadap Jumlah Koloni Bakteri Pseudomonas aeruginosa per $\mathrm{ml}\left(10^{6}\right)$

\begin{tabular}{|l|r|r|r|r|}
\hline \multirow{2}{*}{ Konsentrasi } & \multicolumn{3}{|c|}{ Ulangan } & \multirow{2}{*}{ Rerata } \\
\cline { 2 - 4 } & \multicolumn{1}{c|}{ I } & \multicolumn{1}{c|}{ II } & \multicolumn{1}{c|}{ III } & \\
\hline Kontrol positif (0\%) & 312000 & 299000 & 318000 & 309666.67 \\
\hline $25 \%$ & 303000 & 312000 & 294700 & 303233.33 \\
\hline $30 \%$ & 285000 & 298000 & 291200 & 291400 \\
\hline $35 \%$ & 27900 & 18700 & 15300 & 20633.33 \\
\hline $40 \%$ & 7460 & 8970 & 3590 & 6673.33 \\
\hline $45 \%$ & 1720 & 1530 & 1690 & 1646.67 \\
\hline $50 \%$ & 0 & 0 & 0 & 0 \\
\hline
\end{tabular}

Dari tabel 5 dapat dilihat bahwa rata-rata jumlah koloni bakteri Pseudomonas aeruginosa per $\mathrm{ml}\left(10^{6}\right)$ yang dihasilkan pada media NAP berbeda pada tiap perlakuan konsentrasi. Pada konsentrasi $0 \%$ rata-rata jumlah koloni bakteri Pseudomonas aeruginosa per $\mathrm{ml}\left(10^{6}\right)$ adalah sebesar $309666.67 \mathrm{ml}$. Jumlah rata-rata koloni bakteri Pseudomonas aeruginosa per $\mathrm{ml}\left(10^{6}\right)$ terus mengalami penurunan. Mulai dari konsentrasi $25 \%, 30 \%, 35 \%, 40 \%, 45 \%$ sampai dengan konsentrasi 50\%. Pada konsentrasi 50\% tidak didapatkan pertumbuhan koloni bakteri Pseudomonas aeruginosa per $\mathrm{ml}\left(10^{6}\right)$ pada media NAP. Ditunjukkan dengan jumlah bakteri yang tumbuh adalah (0). Pada penelitian ini KBM ekstrak daun binahong terhadap bakteri Pseudomonas aeruginosa ditentukan pada konsentrasi 50\%, dimana pada konsentrasi ini jumlah koloni bakteri sebanyak 0 (tidak ada bakteri yang tumbuh). 

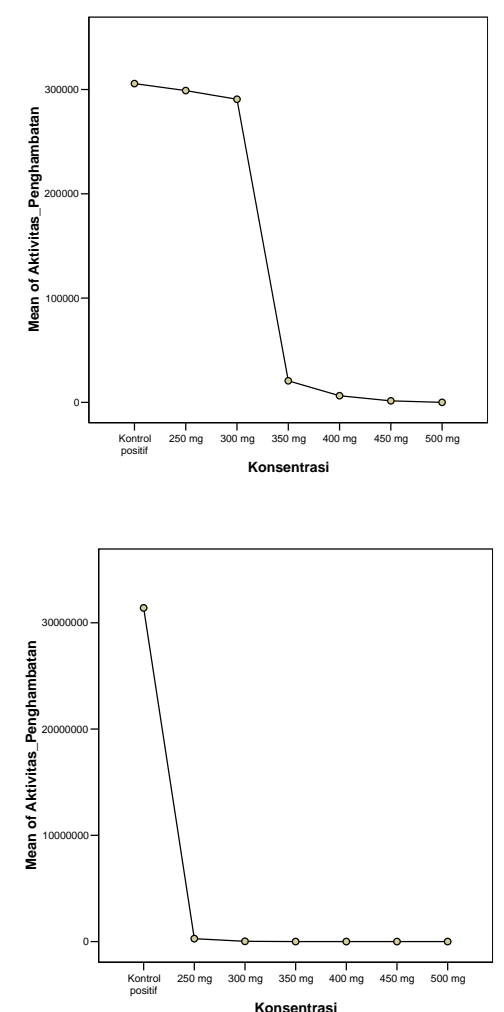

Gambar 1. Grafik Rerata Jumlah Koloni Bakteri Staphylococcus aureus dan Pseudomonas aeruginosa per ml $\left(10^{6}\right)$ dengan Perlakuan Konsentrasi Ekstrak Daun Binahong (Anredera cordifolia (Ten) Steenis)

Gambar 1 menunjukkan variasi konsentrasi ekstrak daun binahong terhadap jumlah koloni masing-masing bakteri yang terbunuh memberikan pengaruh berbeda. Pada bakteri Staphylococcus aureus, daya hambat (KHM) ekstrak binahong terhadap bakteri dimulai pada konsentrasi $25 \%(250 \mathrm{mg} / \mathrm{ml})$ sampai dengan konsentrasi $35 \%$ atau 350 $\mathrm{mg} / \mathrm{ml}$. Sedangkan daya bunuh bakteri (KBM) dimulai pada konsentrasi $40 \%$ atau $400 \mathrm{mg} / \mathrm{ml}$. Pada konsentrasi ekstrak binahong 50\% atau $500 \mathrm{mg} / \mathrm{ml}$, koloni bakteri Staphylococcus aureus sudah tidak teridentifikasi atau 0. Pada bakteri Pseudomonas aeruginosa, daya hambat (KHM) ekstrak binahong terhadap bakteri dimulai pada konsentrasi 25\% (250 $\mathrm{mg} / \mathrm{ml}$ ). Koloni bakteri Pseudomonas aeruginosa sudah tidak teridentifikasi pada konsentrasi ekstrak binahong $30 \%$ atau 300 $\mathrm{mg} / \mathrm{ml}$. Dengan demikian, dapat disimpulkan bahwa daya bunuh ekstrak binahong terhadap bakteri Staphylococcus aureus adalah pada konsentrasi ekstrak binahong 50\% atau 500 $\mathrm{mg} / \mathrm{ml}$, sedangkan daya bunuh ekstrak daun binahong terhadap bakteri Pseudomonas aeruginosa adalah pada daya bunuh ekstrak binahong terhadap bakteri Staphylococcus aureus adalah pada konsentrasi $30 \%$ atau 300 $\mathrm{mg} / \mathrm{ml}$. Penurunan jumlah koloni bakteri pada masing-masing konsentrasi ekstrak binahong secara nyata terjadi pada konsentrasi 25\% (250 $\mathrm{mg} / \mathrm{ml}$ ) sampai dengan konsentrasi 50\% (500 $\mathrm{mg} / \mathrm{ml})$. Hal ini berbeda jauh dengan rata-rata jumlah koloni bakteri pada kontrol (0\%).

\section{Hasil Pengujian Hipotesis}

\section{Uji Konsentrasi Bunuh Minimum (KBM)}

Berdasarkan uji one way ANOVA diketahui bahwa pada variabel terikat jumlah koloni per $\mathrm{ml}\left(10^{6}\right)$ nilai sig $(0,000)<\mathrm{p}(0,05)$ yang berarti terdapat perbedaan yang bermakna atau ada pengaruh perlakuan konsentrasi ekstrak daun binahong terhadap 


\section{Journal of Pharmaceutical Science and Medical Research \\ ISSN 2614-4840 (print) 2614-6118 (online) \\ Vol. 1 No. 1 Tahun 2018}

jumlah koloni bakteri Staphylococcus aureus per $\left(10^{6}\right)$ yang dihasilkan pada media agar plate (NAP). akibat pengaruh perlakuan dari ke-7 variasi konsentrasi ekstrak daun binahong yang diberikan, kemudian untuk mengetahui konsentrasi ekstrak daun binahong mana saja yang berbeda dan tidak berbeda pengaruhnya terhadap pertumbuhan koloni bakteri Staphylococcus aureus tersebut maka dilakukan uji LSD/BNT dari hasil uji LSD/BNT didapatkan hasil bahwa ekstrak daun binahong dengan perlakuan kontrol konsentrasi $(0 \%)$ berbeda nyata dengan perlakuan konsentrasi 30\%, 35\%, 40\%, 45\% dan $50 \%$. Sedangkan pada konsentrasi $25 \%$ berbeda nyata dengan konsentrasi perlakuan yang lain tetapi tidak berbeda dengan konsentrasi kontrol (0\%). Untuk mengetahui adanya arah, kuat, dan pola hubungan antara pemberian konsentrasi ekstrak daun binahong dengan jumlah koloni bakteri per ml $\left(10^{6}\right)$, maka dilakukan uji Korelasi-Regresi. Dari hasil uji Korelasi-Regresi didapatkan ( $\mathrm{r}=$ 0,805) yang artinya terdapat hubungan/korelasi negatif yang kuat antara ke7 konsentrasi ekstrak daun binahong dengan pertumbuhan koloni bakteri Staphylococcus aureus per $\mathrm{ml}\left(10^{6}\right)$. Artinya semakin tinggi konsentrasi ekstrak daun binahong maka jumlah koloni bakteri akan semakin rendah. Besarnya pengaruh konsentrasi ekstrak daun binahong terhadap jumlah koloni bakteri Staphylococcus aureus per $\mathrm{ml}\left(10^{6}\right)$ didapat nilai koefisien determinasi $\left(\mathrm{R}^{2}\right)$ sebesar 0,805 artinya kontribusi pemberian ekstrak daun binahong dalam menurunkan jumlah koloni bakteri Staphylococcus aureus adalah sebesar $80,5 \%$ sedangkan $19,5 \%$ disebabkan oleh faktor-faktor lain yang dapat mempengaruhi hasil penelitian, kemungkinan dapat berasal dari jumlah mikroorganisme, suhu, keasaman (pH) dan bahan-bahan organik lain.

Berdasarkan uji one way ANOVA diketahui bahwa pada variabel terikat jumlah koloni per $\mathrm{ml}\left(10^{6}\right)$ nilai sig $(0,000)<\mathrm{p}(0,05)$ yang berarti terdapat perbedaan yang bermakna atau ada pengaruh perlakuan konsentrasi ekstrak daun binahong terhadap jumlah koloni bakteri Pseudomonas aeruginosa per $\left(10^{6}\right)$ yang dihasilkan pada media agar plate (NAP) akibat pengaruh perlakuan dari beberapa konsentrasi ekstrak daun Binahong yang diberikan.

Setelah mengetahui bahwa ada perbedaan yang bermakna pada jumlah koloni bakteri Pseudomonas aeruginosa per $\mathrm{ml}\left(10^{6}\right)$ yang dihasilkan pada media nutrient agar plate (NAP) akibat pengaruh perlakuan dari ke-7 variasi konsentrasi ekstrak daun binahong yang diberikan, kemudian untuk mengetahui konsentrasi ekstrak daun binahong mana saja yang berbeda dan tidak berbeda pengaruhnya terhadap pertumbuhan koloni bakteri Pseudomonas aeruginosa tersebut maka dilakukan uji LSD/BNT dari hasil uji LSD/BNT didapatkan hasil bahwa ekstrak daun binahong dengan perlakuan kontrol konsentrasi $(0 \%)$ berbeda nyata dengan perlakuan konsentrasi 30\%, 35\%, 40\%, 45\% dan $50 \%$. Sedangkan pada konsentrasi $25 \%$ berbeda nyata dengan konsentrasi perlakuan yang lain tetapi tidak berbeda dengan konsentrasi kontrol $(0 \%)$.

Untuk mengetahui adanya arah, kuat, dan pola hubungan antara pemberian konsentrasi ekstrak daun binahong dengan jumlah koloni bakteri per ml $\left(10^{6}\right)$, maka dilakukan uji Korelasi-Regresi. Dari hasil uji KorelasiRegresi didapatkan $(r=-0,616)$ yang artinya terdapat hubungan/korelasi negatif yang kuat antara ke-7 konsentrasi ekstrak daun binahong dengan pertumbuhan koloni bakteri Pseudomonas aeruginosa per $\mathrm{ml}\left(10^{6}\right)$. Artinya semakin tinggi konsentrasi ekstrak daun binahong maka jumlah koloni bakteri akan semakin rendah. Besarnya pengaruh konsentrasi ekstrak daun binahong terhadap jumlah koloni bakteri Pseudomonas aeruginosa per $\mathrm{ml}\left(10^{6}\right)$ didapat nilai koefisien determinasi $\left(\mathrm{R}^{2}\right)$ sebesar 0,616 artinya kontribusi pemberian ekstrak daun binahong dalam menurunkan jumlah koloni bakteri Pseudomonas aeruginosa adalah sebesar $61,6 \%$ sedangkan $38,4 \%$ disebabkan oleh 


\section{Journal of Pharmaceutical Science and Medical Research \\ ISSN 2614-4840 (print) 2614-6118 (online) \\ Vol. 1 No. 1 Tahun 2018}

faktor-faktor lain yang dapat mempengaruhi hasil penelitian, kemungkinan dapat berasal dari jumlah mikroorganisme, suhu, keasaman (pH) dan bahan-bahan organik lain.

\section{KESIMPULAN}

Berdasarkan data hasil penelitian dapat disimpulkan bahwa ada pengaruh ekstrak daun binahong (Anredera cordifolia (ten.) Steenis) terhadap pertumbuhan bakteri Staphylococcus aureus dan Pseudomonas aeruginosa. Semakin tinggi konsentrasi ekstrak daun binahong maka jumlah koloni bakteri akan semakin rendah. Kontribusi pemberian ekstrak daun binahong dalam menurunkan jumlah koloni bakteri Staphylococcus aureus adalah sebesar 80,5\%. Sedangkan kontribusi pemberian ekstrak daun binahong dalam menurunkan jumlah koloni bakteri Pseudomonas aeruginosa adalah sebesar $61,6 \%$. Masih adanya pertumbuhan Staphylococcus aureus sebesar $19,5 \%$ dan Pseudomonas aeruginosa sebesar 38,4\% disebabkan oleh faktor-faktor lain yang dapat mempengaruhi hasil penelitian, kemungkinan dapat berasal dari jumlah mikroorganisme, suhu, keasaman $(\mathrm{pH})$ dan bahan-bahan organik lain.

\section{DAFTAR PUSTAKA}

Astuti, Sri Murni. 2011. Skrining Fitokimia dan Uji Aktifitas Antibiotika Ekstrak Etanol Daun, Batang, Bunga dan Umbi Tanaman Binahong (Anredera cordifolia (Ten.) Steeni. Artikel. http://artikeledp.files.wordpress.com.

Diakses Maret 2014.

Astuti, Sri Murni, Mimi Sakinah A.M, Retno Andayani B.M, and Awalludin Risch. 2011. Determination of Saponin Compound from Anredera cordifolia (Ten). Steenis Plant (Binahong) to Potential Treatment for Several Diseases. Journal of Agricultural
Science. Vol. 3, No. 4; December 2011. www.ccsenet.org/jas. Diakses Maret 2014.

Das Salirawati. 2009. Manajemen Laboratorium Kimia/IPA. Artikel. http://www.staff.uny.ac.id/manajemenpengelolaan-lab.doc. Diakses Februari 2014.

De padua. 1999. Senyawa Kimia. Http://www.tempo.co.id/medica/arsip/12 2002/art-3.htm. diakses Mei 2014.

Jawetz, E. Melnick, J.L dan Adelberg, E.A. 1996. Mikrobiologi Kedokteran. Surabaya: Salemba.

Jawetz, E. Melnick, J.L dan Adelberg, E.A. 2001. Medical Microbiology Twenty Second Ed. Buku 1. Terjemahan Bagian Mikrobiologi Fakultas Kedokteran Universitas Airlangga. Jakarta: Salemba Medika.

Louis, F.G. 2004. Saponin Glicosides .Georges luis

@ friedli.com,http:www.friedli.com.herb sphytochem.glycosides.html. diakses tanggal Maret 2014.

Manoi, Ferri. 2009. Binahong (Anredera cordifolia) Sebagai Obat. Bulletin Warta Volume 15, Number 1, April 2009. Penelitian dan Pengembangan Tanaman Industri. Badan Penelitian dan Pengembangan Pertanian. Pusat Penelitian dan Pengembangan Perkebunan, Indonesia.

Marinova, D., Ribarova, F., and Atanassova, M. 2005. Total Phenolics and Total Flavonoids in Bulgarian Fruits and Vegetables. Journal of the University of Chemical Technology and Metallurgy. Vol. 40. No. 3. p. 255-260. 
Mayasari, Evita. 2005. Pseudomonas aeruginosa; Karakteristik, Infeksi, dan Penanganan. http://library.usu.ac.id. Diakses Maret 2014.

Pelczar, Michael J, Jr. dan Chan, E.C.S. 1988. Dasar-Dasar Mikrobiologi Jilid 2. Jakarta: UI Press.

Pelczar, Michael J, Jr. dan Chan, E.C.S. 2008. Dasar-Dasar Mikrobiologi Jilid 1. Jakarta: UI Press.

Rahmawati, Lina, Enny Fachriyah, dan Dewi Kusrini. 2013. Isolasi, Identifikasi dan Uji Aktivitas Antioksidan Senyawa Flavonoid Daun Binahong Anredera cordifolia (Ten) Steenis. http://portalgaruda.org/download_article. php? Diakses Maret 2014.

Rahman, Taufik, Nuryani Rustaman, Nana Syaodih, dan Anna Poedjiadi. 2012. Peran Praktikum dalam Membekali Kemampuan Generik Pada Calon Guru (Studi Kasus pada Praktikum Reguler Fisiologi Tumbuhan di LPTK). ejurnal UPI. http://file.upi.edu/Direktori/SPS/. Diakses April 2014.

Robinson, Trevor. 1995. Kandungan Organik Tumbuhan Tinggi, diterjemahkan oleh Prof. Dr. Kosasih Padmawinata. Bandung: Penerbit ITB.

Rustaman, Nuryani Y. 2003. Pendidikan Biologi dan Trend Penelitiannya. Artikel Jurusan Pendidikan Biologi. Tidak Diterbitkan. Bandung: FMIPA UPI.

Setiaji, Ari. 2009. Uji Aktivitas Antibakteri Ekstrak Petroleum Eter, Etil Asetat Dan Etanol $70 \%$ Rhizoma Binahong (Anredera cordifolia (Tenore) Steenis) Terhadap Staphylococcus aureus ATCC 25923 Dan Escherichia coli ATCC 11229 Serta Skrining Fitokimianya.
Skripsi Tidak Diterbitkan. Surakarta: Fakultas Farmasi UMS Surakarta.

Tshikalange T.E, JJM. Meyer and AA. Husein. 2005. Antimicrobial activity, toxicity and the isolation of a bioactive compound from plants used to treat sexually transmitted diseases, Journal of Ethno pharmacology, 96, pp 515-519. http://dx.doi.org/10.1016/j.jep.2004.09.0 $\underline{57}$

Volk and Wheeler. 1988. Mikrobiologi Dasar. Jilid I. Terjemahan .Soenarto. Adisoemarno. Jakarta: Penerbit Erlangga.

Volk and Wheeler. 1990. Mikrobiologi Dasar. Jilid II. Terjemahan .Soenarto. Adisoemarno. Jakarta: Penerbit Erlangga.

Wasis dan Irianto, S. Y. 2008. Ilmu Pengetahuan Alam SMP dan MTs Kelas VIII. Jakarta: Pusat Perbukuan Dep. 
